\title{
"They should work the way we do". The discursive construction of Chinese and Italian cultural identity
}

\author{
"Eles deviam trabalhar como nós". \\ A construção discursiva da identidade cultural chinesa e italiana
}

\author{
Amelia Manuti \\ Roberta Fraccalvieri \\ Giuseppe Mininni \\ University of Bari - Bari - Italy
}

$\diamond$

\begin{abstract}
The Chinese migration is one of the most important migratory flows in the international scene, both for the number of people involved, and for the large and varied number of countries chosen as a destination, including Italy. The present study aimed to study the intercultural dynamics that could arise from the encounter between native (Italian) and immigrants (Chinese), being the Chinese, one of the largest community in Italy. In this vein, the main aim of the study was that of analyzing the relationship between the Chinese and the Italian culture in the south of Italy. Participants were five Italians and five Chinese workers, managers and/or managers of a sample of small and medium-sized enterprises in Bari and in its surroundings. A semi-structured interview was administered as to investigate the interpretative repertoires that both cultures adopt to make sense of work as well as to interpret their reciprocal relationship in the labor market, especially in terms of economical competition in times of crisis. Diatextual Analysis was used as to interpret the data collected. Results showed a difficult integration between the two cultures, especially as for their cohabitation in the labor market.
\end{abstract}

Keywords: Cultural psychology; China; Italy; Discrimination; Labor market; Discourse analysis

Resumo: A migração chinesa é uma das mais importantes vagas migratórias na cena internacional, tanto pelo número de pessoas envolvidas como pela quantidade elevada e variada de países escolhidos como destino, incluindo a Itália. O presente estudo visa estudar a dinâmica intercultural que pode resultar do encontro entre nativos (italianos) e imigrantes (chineses), sendo os chineses, uma das mais numerosas comunidades na Itália. Nesse sentido, o principal objetivo do estudo reside em analisar a relação entre a cultura chinesa e a italiana no sul de Itália. Os participantes foram cinco italianos e cinco chineses trabalhadores, gerentes e/ou gerentes de uma amostra de pequenas e médias empresas localizadas em Bari e nos arredores. Uma entrevista semi-estruturada foi administrada para investigar os reportórios interpretativos que ambas as culturas adotam para que o trabalho faça sentido e também para interpretar a sua relação recíproca no mercado de trabalho, especialmente no que se refere à competição económica em tempos de crise. A Análise Diatextual foi usada para interpretar os dados recolhidos. Os resultados mostraram uma integração difícil entre as duas culturas, especialmente no que se reporta à sua coabitação no mercado de trabalho.

Palavras-chave: Psicologia cultural; China; Itália; Discriminação; Mercado de trabalho; Análise de discurso 


\section{Theoretical background}

Within the last decades, a traditional trend in the field of social sciences has investigated the relationship between levels of cultural exposure and experience with aspects of psychological functioning for immigrant and ethnic minority groups (TSAI, YING and LEE, 2000). Though, few studies have drawn attention on how the meanings attached to being of a particular culture may vary within cultural groups. Yet, those scarce evidences have based on assumptions that the process of acculturation and the concomitant meanings of being of a particular culture could be similar for individuals within a cultural group. Surprisingly, very few studies, however, have actually tested these assumptions. Rather, opposite evidences have largely confirmed that individuals tend to subjectively experience their culture (BERRY, 2005).

In view of the above, the main aim of the present study was to examine how the subjective meanings attached to one's own cultural belonging are actually constructed and conveyed through discourse. Furthermore, the study addressed the rhetorical consequences of these constructions for the way people evaluate cultural diversity and the assimilation of immigrants.

Accordingly, abundant research in discourse studies has investigated the relations between ethnic prejudice and its manifestation in discourse, especially in the context of everyday conversation (VAN DIJK, 1984, 1987a), news reports in the press (VAN DIJK, 1983, 1989) and textbooks (VAN DIJK, 1987b). The main assumption of these studies is that ethnic prejudices are developed, shared and legitimated mainly through various kinds of discursive communication among members of the white dominant group. A systematic analysis of the discourses produced about ethnic minorities may provide important insights into two fundamental aspects of discrimination and stereotypes. First, discourse analysis may tell us something about the content and structure of the cognitive representation of ethnic prejudice, as well as about the properties of their processing during speaking or writing. Secondly, such an analysis could allow to understand exactly how the dominant group members persuasively convey such ethnic prejudices to other ingroup members in communicative interaction and how, thus, ethnic prejudice may spread and become shared within the dominant group.

Indeed, according to this perspective, group prejudice are controlled by the so-called models (VAN DIJK and KINTSCH, 1983), that is mental representations of personal experiences and interactions with ethnic minority group members. These biased, abstract and general group representations mainly contribute to built the ethnic situation models that are generally used to think about and to interact with ethnic minorities' members. As a consequence discourse and communication largely foster the development of interpretative (biased) repertoires of ethnic minorities. As a matter of facts, models are organized in a fixed schema, consisting of categories people use to analyze and understand social situations, e.g., Setting (Time, Location, Circumstances), Participants and Event or Action.

The propositions stored under these categories directly derive both from the personal experience people may have had about a situation, but also from subjective, evaluative beliefs, that is, biased opinions developed and shared within the ingroup. Furthermore, prejudiced beliefs and attitudes about outgroups may also be constructed by copying directly prejudiced opinions from existing attitudes about other ethnic groups. Empirical evidences have largely showed that public and sometimes even institutional talk about minorities could be controlled by such ethnic models. As a consequence, biases in the model may also emerge in conversation, thus conveying, through specific argumentative structures and generalizations, a direct or indirect prejudiced attitude (VERKUYTEN, 2005).

With specific reference to the aims of the present study, attention has been drawn on the meanings attached to "being Chinese" and "being Italian", by looking at how these very different cultural orientations may influence the meaning attached to work, thus in turn producing reciprocal biased views of each other.

The choice of comparing the Italian to the Chinese culture was guided by several reasons. First, Chinese people are one of the largest and most active cultural community in Italy $(0.34 \%$ of the whole Italian population), after Romanians, Albanians and Moroccans. Yet, since the first decade of the XXI century, when the first Chinese sojourners arrived in Italy, generations of Chinese people have been born and raised in Italy (CECCAGNO, 2003). Still nowadays, waves of Chinese immigrants continue to migrate to Italy from China, Hong Kong, Taiwan, and other overseas Chinese communities for reasons that include work, educational attainment, and reunification with family members. As a result, there is tremendous variation in exposure to, and experiences with, Chinese and Italian cultures in Chinese people living in Italy as well as in Italians. Chinese culture has been described as emphasizing interpersonal relationships and the collective, obedience to authority, and emotional moderation and control, whereas mainstream European Italian culture has been described as emphasizing individualism, defiance of authority, and open emotional expression (HSU, 1985; LEE, 1982; RUSSELL and YIK, 1996; ZHENG and BERRY, 1991). 
Despite being one of the largest ethnic minority groups in Italy, relatively little research has been conducted with Chinese people, especially by focusing on the economical challenge that they concretely represent for the Italian market, as long as parallel to their settlement a rapid growth in Chinese business has been registered.

Therefore, by studying Chinese people, the study aimed at examining how variation in cultural exposure and experience influences two cultural orientations that differ immensely in their values and beliefs, sometimes fostering reciprocal misrepresentations and stereotypes. In line with these considerations, as already marked earlier, the present study considered discourse as a privileged context where cognitive and attitude models of cultural encounter may become concrete and sometimes even convey a (biased) representation of both dominant and minority groups. Moving from an applied psycholinguistic approach, the study chose to focus on how participants pragmatically developed their cultural belonging through discourse, thus investigating the strict nexus between identity, texts and contexts of talk.

\section{The study}

\section{Aims, participants, methodology}

Participants to the study were 10 people, 5 Chinese and 5 Italians. Chinese participants were employed mostly in fashion stores and in restaurants. While Italians were employed in different sectors, ranging from information technology company, to alternative energies, to wholesale, to real estate and transportation. As described in the previous section of the paper, the main objective of the study was to investigate the different meaning attached to work in both cultures, focusing on the reciprocal representations participants had of each other that actually was constructed and conveyed through their discourses. Therefore, in-depth narrative interviews were collected. The thematic areas investigated during the interview were referred to personal information (gender, age, country of origin, level of education, profession and since how many time were they staying in Italy) and to information about their relationship with the other culture, in terms of perceived and/or actual discrimination. Interviews took place individually. They were audio-taped and transcribed after participants had having agreed upon it.

Discursive data were processed through Diatextual Analysis, a special address within Discourse Analysis, that is interested in catching the dynamic relationship between texts, contexts and interlocutors (MININNI, 2005). Indeed, in a psycholinguistics perspective, the diatext could be conceived as the dialogue between the text enunciators and their context as it is perceived by them (SLAMA-CAZACU, 1961). Yet, sense does not reside permanently within texts; rather it goes through them as a result of the conjoint action of the enunciators, who negotiate the frame of the situation (stake) which they are actively involved in. Pragmatically speaking, Diatextual Analysis suggests that sense can be caught by answering to three basic questions: Who is saying what? Why does he/she is saying what? How does he/se is saying what? Indeed, the diatextual scholar focuses attention on all the specific discursive markers that leave traces of Subjectivity, Argumentation, and Modality within texts, thus defining the so-called "SAM Model" (MININNI, MANUTI, SCARDIGNO and RUBINO, 2014).

The first question aims at clarifying the way in which texts talk about their interlocutors. Then, the diatextual scholar traces back each discursive markers pointing out the dialogue between the enunciative positions that (through the text) let the identity profile of the ideal author and of the ideal addressee come out. The second question points out an axis of semiotic pertinence which allows discourse to articulate claims, that is to organize "meanings why", and to give voice to reasons and aims which justify why one says something. The third question focuses on the articulation of the "dictum" and of the "modus" of discourse according to which meaning is shaped, that is how it acquires a Gestalt quality which can be evaluated as "good" or "bad", "nice" or "naughty", "effective" or "insipid", etc.

Therefore, being aimed at reconciling "the way people are" with "the way people talk" (MANUTI, TRAVERSA and MININNI, 2012; MANUTI and MININNI, 2013), Diatextual Analysis could be actually considered as a precious psycholinguistic tool to investigate how Chinese and Italians account for their personal experience of cultural relationship in the local context.

\section{Results}

Moving from the theoretical background drawn earlier, the Diatextual Analysis performed on the discursive data collected allowed to highlight how both Italian and Chinese participants differently construct their cultural belonging through discourse.

As for the Chinese group, a first interesting trace in defining their (renewed) cultural identity was linked to the narrative about their arrival in Italy. As in many other similar cultural narratives of migration, Chinese both reported they have been directly and/or indirectly motivated to come to Italy. Some participants underwent emigration as they decided to come to follow their parents and/or other family members, while others made a conscious choice, a voluntary and matured choice. In both cases, the decision making process was long and suffered, based on the accurate analysis of many factors 
such as the economic possibilities, the willingness to adapt to a different socio-cultural context, the willingness to transform or improve their living conditions, the interest and the curiosity to see Italy, the intention to follow the choices of their parents. Discursively speaking, the passive decision to come to Italy was constructed through the use of a "vicarious" agency that is mostly pushed by some significant others ("my brother") to make a decision.

(1) "I came to Italy because his brother was already here, so he told me to come to Italy to work." (Cuin, male - 50 years old)

Indeed, very often, the choice of Italy as a destination was connected with a previous contact that some family members and/or some compatriots already had with the country. Thus the choice and consequent decision were supported by a positive expectation of amelioration of one's own lifestyle. Once made up their mind about the expatriation project, migrants made sense of their experience by finding some good reason to stay as in the following example, where although thinking that the job was not good the Chinese woman justified her choice by saying that she had always desired to come to Italy, whose culture she loved.

(2) "I do not want to go back to China, even if my job is not so good because I love Italy and Italians." (Ying, female -42 years old)

Though this initial positive impact with Italy as hosting country, the Chinese accounts of migration mostly underlined some important differences between the two cultures. The most evident one was the meaning of work and money.

Chinese entrepreneurs generally told that although living in Italy they didn't change their habits. They usually lived where they work, namely in the factory, and kept a simple lifestyle, which is typical of their culture. By this, affording low costs of accommodation they could easily save money to improve their business and/or to send money home. As well-known, the Chinese culture is a work-centric culture where work is not seen as a mean to subjective well-being rather as a collective resource to serve the community. In this vein, even if living and working in a totally different culture, the Italian one, the Chinese people involved in the study confirmed their strong attachment to their culture and the deep identification with its core values.

(3) "My husband and I live in a small apartment and pay rent, when no money we call mom and they send money from China." (Ying, female -42 years old)
Instead of simply observing this peculiar attitude toward work, that of course led to economical growth, Italians took this chance to manifest hostility toward the Chinese people who were generally labeled as "invaders" of the Italian labor market. Yet, their economical competitiveness, which actually is function of the Chinese work ethic, was perceived as a threat by the Italians who discursively constructed this opposition actually as a cultural clash. As showed by the following extract, Italians discursively construct the relationship with the Chinese by using the analogical script of the fighting battle, where the power of an actor is manifested in his/her ability to "dominate", to "climb over positions" thus making the situation a serious threat.

From a pragmatic point of view, in extract 4 all the three markers of diatextual analysis could be pointed out. Subjectivity was described through the opposition between personal pronouns ("we/they") that actually shaped the competitive relationship. Argumentation indirectly (re)shaped the Italians/Chinese people relationship by inverting the equivalence between dominant/minority group. Accordingly, the interlocutor described Italians as victims of this "serious threat" instead of the dominant hosting culture. Finally, Modality allowed to catch the nexus between the text and the identity of the speaker by focusing on some specific meta-discursive cues and affective markers (e.g. the use of the adjective "hard" or of the adverb "rapidly") that actually contribute to increase the sense of invasion and difficulty experience by the Italians who have to face the Chinese economical competition.

(4) "If they continue pushing this way it will rapidly become very hard to be able to climb over other positions that is to share other slices of the market that they have took us. It is becoming a serious threat [...] in a few years they will dominate the whole labor market." (Pasquale, male -26 years old)

In a similar vein, Italian entrepreneurs were also very polemic with the Italian government, since they accused it to encourage the diffusion of the Made in China to the detriment of the Made in Italy. The following extract was also an example of the allusive language used by Italians to describe the co-habitation with the Chinese community. By saying that $€ 2,000$ "do not come out of nowhere" the speaker was indirectly saying that this sum came from an ambiguous (maybe criminal) source. Indirectly he was discriminating Chinese people, by generalizing and thus by using a biased language he contributed to foster and legitimize racism and prejudice through discourse. 
(5) " $€ 2,000$ to rent a place run by Chinese merchants do not come out of nowhere." (Pasquale, male - 26 years old)

Nonetheless, while talking about their work ethic, Italians told that the Chinese entrepreneurial success was mostly deserved because of their complete devotion to work. Though, they directly condemned this success, since in the current economical situation, it represented one of the main cause of insecurity, despair and surrender for many Italian entrepreneur. Accordingly, Italians mostly felt that they were yielding this competition: the rapid diffusion of Chinese competitive goods in Italy, their lower prices, their wider offer, the disengagement of the Italian government toward this situation, though the serious economical crisis, were some of the main reasons that have led the Italian entrepreneurs to lose their self-confidence and enthusiasm, that have led most firms to go bankrupt and some managers even to commit suicide. By their side, Chinese criticized with the Italian way of experiencing work, according to them Italians did not devote to work as much as Chinese people did. Moreover, as long as Italians strongly attacked the economical growth brought about by the Chinese business, by hinting to their criminal affairs and to their ambiguous participation to the "yellow mafia", Chinese participants did not lose occasion to remark that the same could be said for Italy, where violence and organized criminality were similarly diffused.

In this vein, the following example clearly underlined the feeling of prejudice experienced by Chinese people in Italy. Very often Chinese people were (negatively) categorized through fallacies and stereotypes. Italians generally think that Chinese work too much and are unhappy, that Chinese overstock money to make dirty business. The speaker in the following extract disconfirmed these biased views, reaffirming his honesty as well as his countrymen's honesty (e.g. through repeating the pronoun "we") in paying taxes even if experiencing the same economical crisis as Italians. Indirectly he condemned the Italian lifestyle while saying that "we are happy even if we earn a few money", thus hinting to the typically Italian concern with the "bella vita".

(6) "We work more than Italians do. We are happy even if we earn a few money. Italians say that we have a lot of money, but it's not true, we are experiencing crisis too. We pay taxes, everything in order [...] in China, of course there are criminals, but also here in Italy it is not so quiet, I watch the TV and see that many people is being killed in Italy too." (Cuin, male - 50 years old)

Though conscious of the Chinese abilities to make business, Italian entrepreneurs generally attributed their success to the very low cost of manpower. Then, both cultures reciprocally adopt the attributional bias, typically marking the difference between the ingroup and the outgroup. Yet, both groups of participants tended to describe the other by focusing on his most negative features, as to depreciate his challenging identity (TINGTOOMEY et al., 2000). As in the precious example, extract 7 focused on a typical fallacy about Chinese people, namely their being a big population ("they are too many"). In view of the above, the Italian speaker insisted on this feature, as to justify once more the Chinese economical success in the name of the wider possibilities these workers have to find even more skillful collaborators and thus to win the battle for the control over the market ("they are always winners").

(7) "They are too many, if they have problems with a collaborator, they replace him with some other [...] by working this way they are always winners." (Pasquale, male- 26 years old)

As for the meaning attached to work, the interviews showed a rather different representation between the two cultures. The narratives of the Chinese people showed a focus on the extrinsic meaning of work, that is on the dimension of economical gain and status acknowledgment. Such evidence was further amplified by the Italian accounts where Chinese were generally described as monsters, mostly interested in making business even at the expenses of their personal identity. Yet, through the use of such a powerful metaphor, Italians violently attacked the Chinese credibility, their special intuition for business and even the concrete positive results gained in the Italian market, by evoking their insane work ethic that actually transforms human beings into monsters.

(8) "In the working context they are monsters because they are interested in business even to the detriment of human respect and dignity, they only work for profit. They are clever since they succeed in producing a lot but it is no good since there is no respect for the people $[\ldots]$ it is scandalous they produce in inhuman conditions $[\ldots]$ you only care for business and profit and not to the person and this is no good." (Pasquale, male -26 years old)

Conversely, being their culture a work-centric culture, Chinese people criticized with the Italian lifestyle. According to them, Italian did not devote to work enough, that is why most Italian companies were going bankrupt. By remarking their position they tended to introduce their lifestyle as the right one, thus remarking once more the 
opposition between "we good/you bad" that is a typical feature of difficult cultural encounters.

(9) "In my opinion Italy must do as we do, they should work the way we do." (Lin, female -30 years old)

The following extract was a good example of this oppositional cultural dynamic, since the Chinese interlocutor shifted from talking about Italians as a general abstract category in terms of "they" to judging the Italian researcher who is collecting the data by referring to her as "you". This passage exemplified the sense of exclusion experienced by Chinese people in Italy, who felt themselves actually as strangers.

(10) "The relationship with Italians not so good because they do not accept us, they do not accept Chinese people working here in Italy, they do not look positively at us, you look negatively at us." (Lin, female -30 years old)

This perception was amplified by some of the Italian participants, who strongly claimed to be the dominant group. Once more the sense of threat described earlier let the speaker of the following extract underline the superiority of the Italian culture and the obligation for Chinese to subdue to the Italian culture.

(12) "Chinese people should adapt to our culture, is should be the Italian culture that would play influence on the Chinese culture, that is why there should be no Chinese school in Italy." (Nicola, male- 28 years old)

In this perspective, the Italian speaker continued affirming the Italian superiority by implicitly saying that the Italian work style was better than the Chinese one, labeled as inhuman. Diatextually speaking it was very interesting the reference to the word "racism" that was immediately withdrawn by the interlocutor since he was fully aware of all its destructive power. Nonetheless, the argumentation he posited after his consideration confirmed his biased and then racist view of Chinese workers.

(13) "I'd like Italians to work in China and not the contrary but not as a form of racism, only because I do not like the way they work, it is against humanity." (Nicola, male -28 years old)

Although the evident difficulties encountered by Chinese people in Italy, unlike the Italians interviewed, some of Chinese migrants involved in the study showed themselves to be more inclined to dialogue and integration with the hosting culture. They told that they engaged in learning Italian very quickly, they even decided to give their children Italian names. Both are very significant steps toward actual integration, although as emerged in the following example, the second generation of migrants manifested a stronger push toward cultural maintenance than their parents.

(14) "I have also called my children with Italian names: Simone and Alessandro. Simone returned to China with his grandparents because he wants to learn Chinese and said he wants to be first Chinese, then Italian." (Ying, female -42 years old)

\section{Conclusion}

The results coming from the study above have contributed to show the relevance of considering psycholinguistic research as a confederate of crosscultural studies. Yet, investigating how social groups talk about each other is very important both for the progress of theory as well as to deconstruct the stereotypes that are largely circulating in social discourse as well as to plan and carry out dedicated policies and interventions.

The focus on the relationship between the Italians and Chinese, that actually was the case study presented, allowed to highlight the complexity of the process of acculturation which constantly oscillates between separation and integration, between threats and opportunities. In this frame, Diatextual Analysis has contributed to show the very strong connection between discourse and identity since to talk about something is actually to be someone. In line with such evidence, to study how dominant and minority groups reciprocally talk about themselves has allowed to go beyond any popular rhetoric about discrimination and racism, showing that language and communication are actually the place where cultural stereotypes, fallacies and biases are cherished first of all to protect one's personal identity. Indeed, the case study presented has showed that the simple co-habitation between these two cultures, the Chinese and the Italian one, was differently perceived by the participants. For Italians, it was described as an invasion, as an attack, as a challenge rather than as an opportunity toward multiculturalism and an actual multiethnic society. For Chinese people, though all their efforts toward integration, Italy mostly represented a foreign land, where the main and easier option in the acculturation process was to chose cultural maintenance. In this perspective, the psycholinguistic approach applied to the discursive data collected in the interviews proved itself to be a precious chance as to identify some of the repertoires deployed in talking about immigration and to examine how these were used rhetorically to manage intergroup and multicultural 
relationships. This examination showed the complexities and dilemmas of the interpretative processes, that actually guide cultural integration, meant first of all as a cognitive and a discursive elaboration. Then, the study contributed to highlight that cultural integration could actually start in discourse, as long as through their communicative practices groups and communities are actively engaged in constructing realities and arguing about responsibilities and implications. In a word, they concretely shape and convey the representations (of the self and the other) that actually substantiate cultures.

\section{References}

BERRY, J. Acculturation: Living successfully in two cultures. International Journal of Intercultural Relations, v. 29, n. 6, p. 697-712, 2005. http://dx.doi.org/10.1016/j.ijintrel.2005.07. 013

CECCAGNO, A. New Chinese Migrants in Italy. International Migration, v.41,n.3,p. 187-213, 2003.http://dx.doi.org/10.1111/ $1468-2435.00246$

HSU, F. The self in cross-cultural perspective. In: MARSELLA, A. J.; DeVOS, G.; HSU, F. (Ed.). Culture and self: Asian and Western perspectives. NewYork: Guilford, 1985. p. 24-55.

LEE, E. A social systems approach to assessment and treatment for Chinese American families. In: MCGOLDRICK, M.; GIORDANO, J. (Ed.). Ethnicity and family therapy. New York: Guilford, 1982. p. 527-551.

MANUTI, A.; MININNI G. Narrating organizational change: an applied psycholinguistic perspective on organizational identity. Text \& Talk, v. 33, n. 2, p. 213-232, 2013.

MANUTI, A.; TRAVERSA, R.; MININNI, G. The dynamics of sense making: a diatextual approach to the intersubjectivity of discourse. Text and Talk, v. 32, n. 1, p. 39-61, 2012. http:// dx.doi.org/10.1515/text-2012-0003

MININNI G. Diatexts as a Mirror of Human Complexity. World futures: The Journal of General Evolution, v. 61, p. 165-173, 2005.

MININNI, G.; MANUTI., A.; SCARDIGNO, R.; RUBINO, R. Old Roots, New Branches: The Shoots of Diatextual Analysis. Qualitative Research in Psychology, v. 11, p. 1-16, 2014.
RUSSELL, J. A.; YIK, S. M. Emotion among the Chinese. In: BOND, M. H. (Ed.). The handbook of Chinese psychology. Hong Kong: Oxford University Press, 1996.

SLAMA CAZACU, T. Langage et contexte. The Hague: Mouton, 1961.

TING-TOOMEY, S.; YEE-JUNG, K. K.; SHAPIRO, R. B.; GARCIA, W.; WRIGHT, T. J.; OETZEL, J. G. Ethnic/Cultural Identity Salience and Conflict Styles in Four US Ethnic Groups. International Journal of Intercultural Relation, v. 24, n. 1, p. 4781, 2000. http://dx.doi.org/10.1016/S0147-1767(99)00023-1

TSAI, J.; YING, Y.; LEE, P. The meaning of "being American" and "being Chinese". Variation Among Chinese American Young Adults. Journal of Cross-Cultural Psychology, v. 31, n. 3, p. 302332, 2000. http://dx.doi.org/10.1177/0022022100031003002

VAN DIJK, T. A. Discourse analysis: Its development and application to the structure of news. Journal of Communication, v. 33, n. 2, p. 20-43, 1983.

VAN DIJK, T. Prejudice in Discourse. Amsterdam: Benjamins, 1984. http://dx.doi.org/10.1075/pb.v.3

VAN DIJK, T. Communicating Racism. Newbury Park: Sage, $1987 \mathrm{a}$.

VAN DIJK, T. Episodic models in discourse processing. In: HOROWITZ, R.; SAMUELS, S. (Ed.). Comprehending oral and written language. New York: Academic Press, 1987b. p. 161-196.

VAN DIJK, T. Social cognition and discourse. In: GILES, H.; ROBINSON, R. (Ed.). Handbook of Social Psychology and Language. Chichester: Wiley, 1989. p. 163-183.

VAN DIJK, T.; KINTSCH, W. Strategies of Discourse and Comprehension. New York: Academic Press, 1983.

VERKUYTEN, M. Immigration discourses and their impact on multiculturalism: a discursive and experimental study. British Journal of Social Psychology, v. 44, p. 223-240, 2005. http://dx.doi.org/10.1348/014466604X23482

ZHENG, X.; BERRY, J. Psychological adaptation of Chinese sojourners in Canada. International Journal of Psychology, v. 26, p.451-470, 1991.http://dx.doi.org/10.1080/00207599108247134

Recebido: 30 de agosto de 2014

Aprovado: 05 de novembro de 2014

Contato: amelia.manuti@uniba.it 